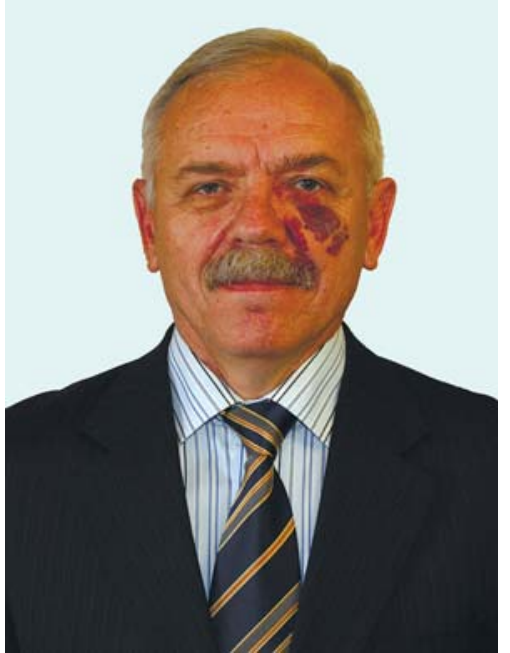

ВОВК

Михайло Володимирович член-кореспондент НАН України, доктор хімічних наук, професор, директор Інституту органічної хімії НАН України

\section{АСИМЕТРИЧНИЙ ОРГАНОКАТАЛІЗ - НОВІТНЯ СТРАТЕГІЯ КОНСТРУЮВАННЯ ХІРАЛЬНИХ МОЛЕКУЛ ДЛЯ СУЧАСНОЇ ТЕХНІКИ, ТЕХНОЛОГІЇ ТА МЕДИЦИНИ}

\author{
Нобелівська премія з хімії 2021 року
}

В короткій оглядовій статті відображено ключові аспекти формування та розвитку впродовж останніх 20 років асиметричного органокаталізу як нового потужного інструменту для конструювання хіральних органічних молекул. Відзначено роль твориів стратегії асиметричного органокаталізу - Беньяміна Ліста і Девіда Макміллана, яких у 2021 р. було удостоєно Нобелівської премії з хімії. Розкрито принципові переваги органокаталітичної методологї порівняно з іниими методами асиметричного синтезу. Проаналізовано найтиповіші способи активащї асиметричних органокаталізаторів та описано нові напрями їх використання. Особливу увагу приділено результатам досліджень вітчизняних науковців у галузі асиметричного органокаталізу.

Ключові слова: асиметричний органокаталіз, хіральні молекули, способи активації органокаталізаторів, досягнення українських дослідників.

Творці органокаталізу - лауреати Нобелівської премії з хіміï за 2021 р. Співтовариство вітчизняних хіміків-органіків, насамперед дослідники в галузі асиметричного органічного синтезу, з великим задоволенням і піднесенням зустріли повідомлення про присудження у 2021 р. Нобелівської премії з хімії професору Беньяміну Лісту (Benjamin List), директору Інституту дослідження вугілля Товариства Макса Планка (Hiмеччина) та професору Девіду Макміллану (David MacMillan) із Принстонського університету (США) за розроблення та розвиток нового точного інструменту для побудови хіральних органічних молекул - асиметричного органокаталізу.

Як зазначив професор Йохан Еквіст, голова Нобелівського комітету з хімії, запропонована лауреатами «концепція каталізу наскільки ж проста, як і геніальна, тож багато людей дивуються, чому ми не додумалися до неї раніше». Ефективність та синтетична універсальність асиметричного органокаталізу 


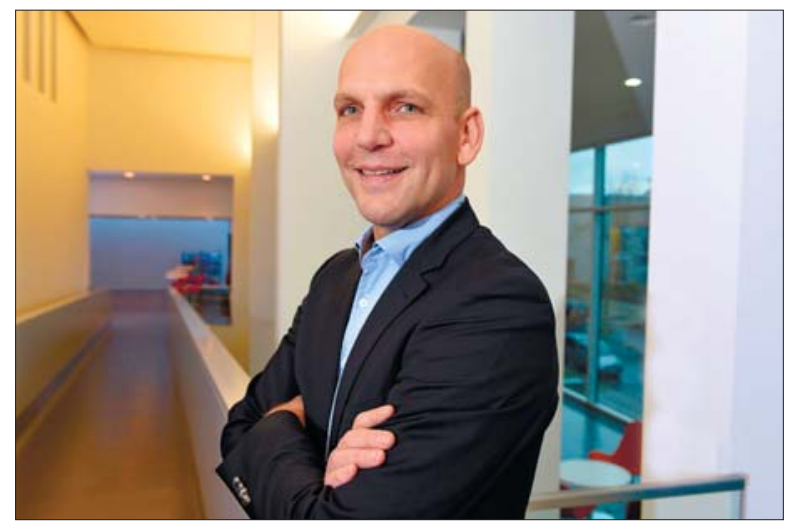

Фото ( ) David Ausserhofer / MPG

БЕНЬЯМІН ЛІСТ (Bеnjamin List) - німецький хімік-органік, директор Інституту дослідження вугілля Товариства імені Макса Планка (Max-Planck-Instituts für Kohlenforschung). Народився 11 січня 1968 p. y Франкфурті-на-Майні в родині з давніми традиціями y природничій сфері: його прапрадід Якоб Фольхард (1834-1910) був відомим хіміком, учнем Юстуса фон Лібіха, прадід Франи Фольхард (1872-1950) - знаним нефрологом, а його тітка Крістіана Нюсляйн-Фольгард у 1995 р. стала лауреатом Нобелівської премії з фізіології та медицини за відкриття, пов'язане з генетичним контролем на ранніх стадіях ембріонального розвитку.

у 1993 р. Б. Ліст здобув ступінь бакалавра з хімії у Вільному університеті Берліна, у 1997 р. - ступінь PhD y Франкфуртському університеті імені Йоганна Вольфганга Гете (дисертація була присвячена синтезу вітаміну $B_{12}$ ). Потім переїхав у США, де прачював спочатку як постдок у Дослідницькому інституті Скріпnса (The Scripps Research Institute) в Ла-Хоя (uтат Каліфорнія), а в 1999 р. став дочентом. У 2003 р. повернувся до Німеччини і очолив дослідницьку групу в Інституті дослідження вугілля Товариства імені Макса Планка, у 2005 р. став директором иього Інституту $i$ завідувачем відділу гомогенного каталізу. 32004 р. Б. Ліст є почесним професором органічної хіміӥ в Кельнському університеті, з 2018 р. - головним дослідником Інституту дизайну та відкриття хімічних реакцій Університету Хоккайдо (Японія) за сумісництвом, крім того, він - головний редактор журналу Synlett. На початок 2021 р. його індекс Гірша за даними Sсориз становив 86.

Беньямін Ліст - член Німецької національної академії наук Леопольдина, неодноразово був відзначений як один з найчитованіших дослідників, лауреат багатьох наукових премій, зокрема премії Отто Баєра (2012), премії Горста Пращеюса (2013), премії Мукаями (2013), премії Коупа (2014), премії Лейбніча (2016). мали значний вплив на сферу органічного синтезу з початку 2000-х років. У процесі свого розвитку асиметричні органокаталітичні методи вийшли за межі академічних кіл, їх почали використовувати для виробництва хіральних ліків, природних продуктів та енантіомерно збагачених біоактивних молекул. Оцінюючи значення розробленої асиметричної органокаталітичної стратегії, у пресрелізі Нобелівської премії відзначено, що «за допомогою цих реакцій дослідники тепер можуть більш ефективно конструювати будь-що - від нових фармацевтичних препаратів до молекул, які спроможні вловлювати світло в елементах сонячних батарей. Таким чином органокаталізатори приносять найбільшу користь людству».

Галузь асиметричного каталізу, яка займається створенням ефективних каталітичних методів для побудови хіральних молекул, тривалий час вирізнялася домінуючим використанням металоорганічних сполук та ферментів. Однак в останні два десятиліття завдяки опублікованим у 2000 р. піонерським працям цьогорічних нобелівських лауреатів концепція органокаталізу як третього виду асиметричного каталізу перетворилася на дискретну стратегію розв'язання сучасних завдань хімії. Зокрема, Б. Ліст звернув увагу на те, що у складі більшості ферментів є атоми металів, але деякі хімічні перетворення каталізуються без їх участі, а деякі «запускаються» однією або кількома амінокислотами у ферменті, і запропонував використати амінокислоту пролін як асиметричний органокаталізатор [1]. Д. Макміллан підійшов до цієї ідеї з дещо іншої позиції. Він зауважив, що розроблені на основі металів хіральні каталізатори рідко застосовують у виробничих масштабах через їх високу вартість та складність використання (необхідність відсутності вологи та кисню в реакційному середовищі). Д. Макміллан запропонував використовувати як каталізатори невеликі органічні молекули і ввів у науковий обіг термін «асиметричний органокаталіз» [2]. На сьогодні асиметричний органокаталіз визнано як незалежний синтетичний інструмент поряд 3 асиметричним металокаталізом та фермента-

ISSN 1027-3239. Visn. Nac. Acad. Nauk Ukr. 2021. (12) 
тивним каталізом для синтезу енантіомерно збагачених хіральних органічних сполук.

Упродовж останніх 20 років стратегію асиметричного органокаталізу було реалізовано на більш як 150 різнотипових органічних реакціях. Кожен із цьогорічних нобелівських лауреатів опублікував понад 200 оригінальних наукових праць 3 проблем асиметричного органокаталізу, показники цитування яких перевищують 33 000. В останнє десятиліття щороку з'являється приблизно 1500 публікацій, пов’язаних з органокаталізом. Зусилля Д. Макміллана з поєднання органокаталізу та фотоокиснювального каталізу [3] стали ще однією яскравою сторінкою в енантіоселективній функціоналізації складних молекул. Знаменно, що ІЮПАК (Міжнародний союз фундаментальної та прикладної хімії) у 2019 р. визначив енантіоселективний органокаталіз як одну з 10 нових технологій у хімії, які можуть зробити нашу планету більш стійкою [4].

Принципові переваги органокаталітичної стратегіï. До кінця 1990-х років асиметричний каталіз грунтувався переважно на використанні металовмісних хіральних каталізаторів, які дозволяли проводити процеси окиснення, відновлення, вклинення б-зв'язків, активацію $\pi$-зв'язків, а також реакції, що каталізуються кислотами Льюїса. Загалом вплив каталізаторів на основі металів не варто недооцінювати, хоча деякі металоорганічні системи є високовартісними, токсичними та чутливими до дії повітря і вологи.

Поява асиметричного органокаталізу відкрила нові шляхи і надала переваги [5], пов’язані з економією матеріальних ресурсів, часу та енергії, спрощенням експериментальних методик і скороченням обсягів хімічних відходів, що зумовлено впливом кількох суттєвих факторів. По-перше, органічні молекули генетично не чутливі до дії атмосферного кисню та вологи, внаслідок чого зникає потреба у використанні спеціальної експериментальної техніки, а також надсухих реагентів та розчинників. По-друге, широкий спектр таких органічних реагентів, як амінокислоти, гідроксикислоти та вуглеводи, є природно доступними з біоло-

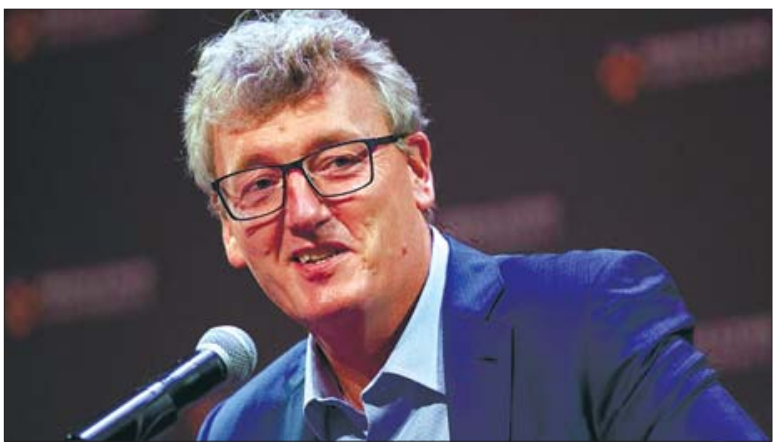

Фото (C) Bryan R. Smith / AFP

ДЕВІД МАКМІЛЛАН (David MacMillan) - британсько-американський хімік-органік, заслужений професор хімії Принстонського університету. Народився 16 березня 1968 р. у шотландському містечку Беллсхілл неподалік від Глазго.

Після закінчення школи навчався в Університеті Глаз2о, здобувши там у 1991 р. ступінь бакалавра з хімії. Потім перейхав до США, де вступив у докторантуру до професора Ларрі Овермана в Каліфорнійському університеті в Ірвайні. Ступінь PhD здобув у 1996 р. у Гарвардському університеті. Незалежну дослідницьку кар'єру розпочав у 1998 р. в Каліфорнійському університеті в Берклі, а потім, у 2000 р., перейшов до Каліфорнійського технологічного інституту на кафедру органічної хімії, де займався пошуком нових підходів до енантіоселективного каталізу, став професором. У 2006 р. переїхав на східне узбережжя США, обійнявши посаду заслуженого професора в Принстонському університеті, де з 2010 по 2015 р. завідував кафедрою хімії. На початок 2021 р. його індекс Гірша за даними Sсория становив 100.

Д. Макміллан - член Лондонського королівського товариства (2012), Американської академії мистецтв та наук (2012), Національної академії наук США (2018). Був засновником і головним редактором (2009-2014) журналу Chemical Sciences Королівського хімічного товариства. Має багато наукових відзнак, серед яких медаль Корде-Моргана (2005), премія Гаррісона Хова (2014), Гарвардська премія Макса Тішлера (2016), премія Рьодзі Нойорі (2018), медаль Нагої (2019).

Крім того, Д. Макміллан є науковим консультантом у таких відомих компаніях, як Pfizer, Merck, Amgen, Biogen Biopharma, Abbvie Research Laboratories, Johnson E Johnson Pharmaceuticals, UCB-Celtech, Constellation Pharmaceuticals, Takeda Pharmac Research Laboratories, a також иленом наукових консультативних рад компаній Firmenich (Швейцарія) та Kadmon Pharmaceuticals (США), nостійним членом ради RSRC у дослідницьких лабораторіях Merck. Співзасновник біотехнологічної компанії Chiromics $L L C$, яка розробляє нові стратегї та методи скринінгу для ідентифікації молекул при створенні ліків. 
гічних джерел у вигляді окремих енантіомерів. Саме тому прості органокаталізатори зазвичай дешеві у приготуванні, доступні в необхідних кількостях і підходять для проведення як лабораторних досліджень, так і реакцій у промисловому масштабі. По-третє, малі органічні молекули, як правило, не токсичні та екологічно безпечні, що значно підвищує безпеку застосування каталізу у хімічних і біологічних дослідницьких комплексах.

Що стосується промислового використання, то асиметричні органокаталітичні реакції є вкрай корисними для медичної хімії, технологічні потреби якої часто відрізняються від потреб класичного хімічного виробництва та розроблення процесів. Для медичної хімії ключовим є пошук швидких і таких, які мають широкий діапазон застосування, способів створення нових кандидатів у ліки для тестування, через що найважливішими критеріями для каталізаторів є їх універсальність, зручність та надійність. Саме органокаталізатори відповідають цим експлуатаційним вимогам, і їх було взято на озброєння в процесах пошуку терапевтичних засобів, збагачених певним енантіомером [6]. Розвиток асиметричного органокаталізу, який використовує як хіральні каталізатори такі невеликі органічні молекули, як похідні алкалоїдів, амінокислот та фосфорних кислот, значно розширив хімічний простір, який можна використати для отримання синтетичних блоків та ключових сполук. Саме тому ця стратегія особливо приваблива для конструювання біологічно активних молекул, які зазвичай не толерантні до забруднення металами.

Режими активаціі та реакційна здатність асиметричних органокаталізаторів. Найважливішою передумовою успіху органокаталізу в перше десятиліття його відкриття була ідентифікація загальних режимів активації, індукції та реакційної здатності каталізатора. Загальний режим активації описує реакційний вид, який може брати участь у багатьох типах реакцій з незмінно високою енантіоселективністю. Такого роду реакційні види виникають у результаті взаємодії одного хірального каталізатора з основною функціональною групою (карбонільною, алкенільною, імінною тощо) y високоорганізованому i передбачуваному процесі. Значущість типових режимів активації полягає в тому, що після їх встановлення вони можуть відносно просто бути використані в ролі платформи для розроблення нових енантіоселективних реакцій. Дійсно, більшість 3 понад 150 органокаталітичних реакцій грунтуються безпосередньо на 5 або 6 режимах активації. Не видається дивним незначне число варіантів активації в асиметиричному органокаталізі (як і в каталізі загалом), оскільки при розробленні нової енантіоселективної реакції набагато простіше використати відомий спосіб активації, ніж винаходити його новий різновид разом з новим каталізатором. Як результат, кількість енантіоселективних каталітичних реакцій завжди буде значно більшою за число режимів активації, які лежать в їх основі. Найпоширенішими способами активації асиметричних реакцій на сьогодні є єнамінокаталіз, імінієвий каталіз та каталіз з утворенням водневих зв'язків (див. табл.) [5].

Незважаючи на те, що перші повідомлення, присвячені каталізованій амінокислотою проліном енантіоселективній внутрішньомолекулярній альдольній реакції для синтезу кетона Віланда-Мішера, було опубліковано ще в 1971 р. [7, 8], режим активації, який лежав в ㄲï основі, не використовували впродовж наступних 30 років. І лише після появи у 2000 р. базової праці Б. Ліста зі співробітниками [1] 3 використання проліну для $\alpha$-функціоналізації карбонілвмісних сполук єнамінокаталіз набув значного поширення. 3 того часу велику кількість досліджень було спрямовано на виявлення нових типів єнамінових каталізаторів. 3 точки зору механізму єнаміновий каталіз можна описати як двофункціональний процес, оскільки аміновмісний каталізатор (пролін у табл.) взаємодіє з кетоновим субстратом з утворенням єнаміну як проміжного продукту, але одночасно він реагує з електрофільним партнером через водневий зв'язок або електростатичне притягання.

Імінієвий каталіз був першим органокаталітичним способом активації, представленим як

ISSN 1027-3239. Visn. Nac. Acad. Nauk Ukr. 2021. (12) 
Загальні способи активації, які найчастіше використовують в органокаталізі

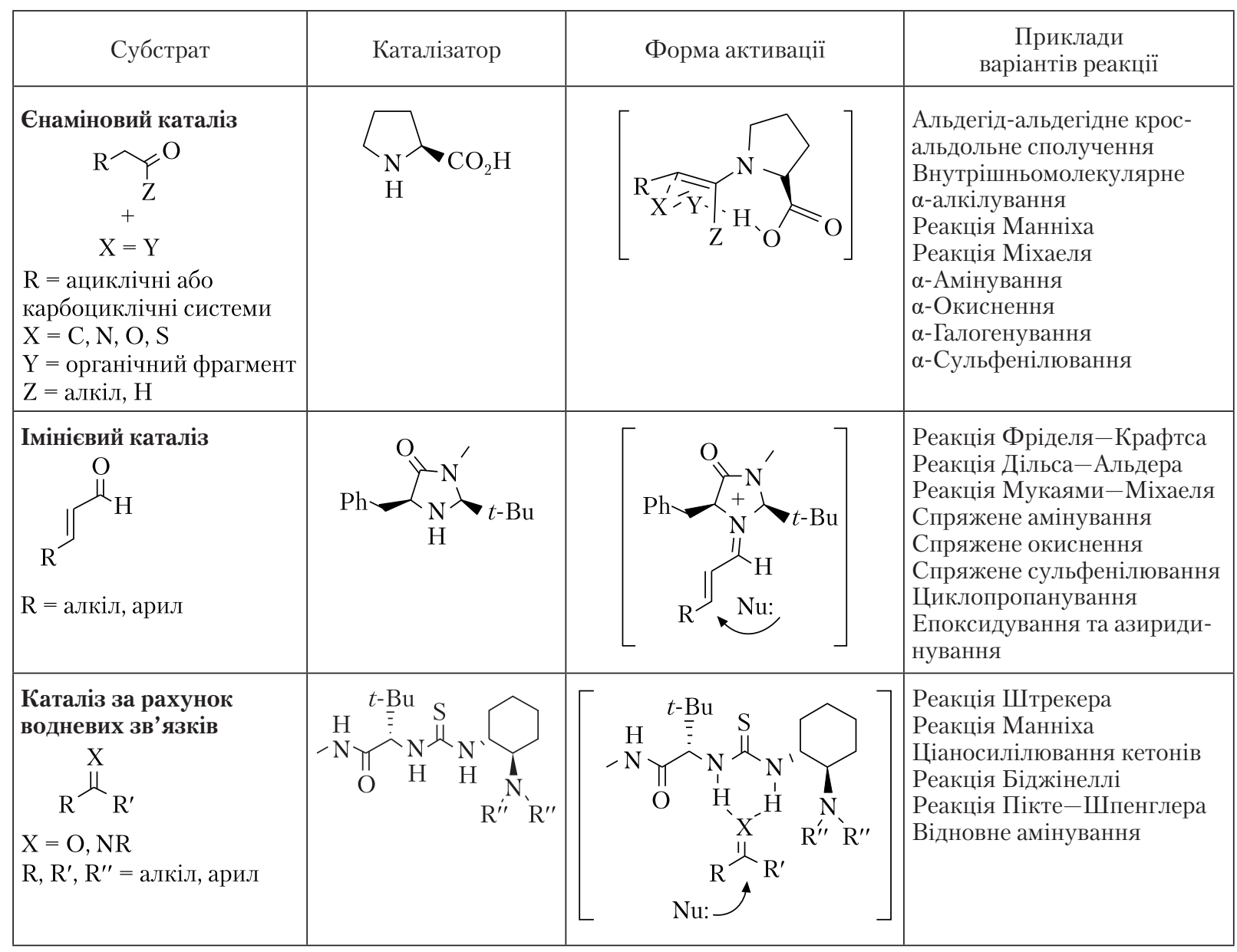

загальна стратегія асиметричного органічного синтезу. Він оснований на здатності хіральних амінів функціонувати в ролі енантіоселективних каталізаторів для кількох перетворень, у яких традиційно використовується каталіз кислотами Льюїса. Концепція механізму грунтувалася на гіпотезі про те, що оборотне утворення імінієвих іонів з $\alpha, \beta$-ненасичених альдегідів і хіральних амінів може імітувати рівноважні динамічні і $\pi$-орбітальні електронні процеси, характерні для каталізу кислотами Льюїса. Завдяки індивідуально розробленій серії імідазолідинонових каталізаторів імінієвий каталіз сьогодні використовується в понад 50 високоенантіоселективних протоколах, більшість 3 яких було розроблено дослідницькою групою Д. Макміллана [9].
Каталіз за участю водневих зв'язків розпочався $з$ того, що на початку 1980-х років було виявлено декілька асиметричних каталітичних процесів, які дозволили зробити припущення, що активація субстрату і організація перехідного стану можуть відбуватися через визначені процеси внаслідок утворення водневих зв'язків $[10,11]$. Однак їх розглядали як виняток із загальноприйнятого положення про те, що водневий зв’язок є недостатньо активуючим або направленим для використання його в асиметричному каталізі. Дещо пізніше [12] ці міркування було спростовано повідомленнями про асиметричний варіант реакції Штрекера, в якому використовували схильні до утворення водневих зв'язків каталізатори, що активували іміновмісні електрофіли. Було показано, що 


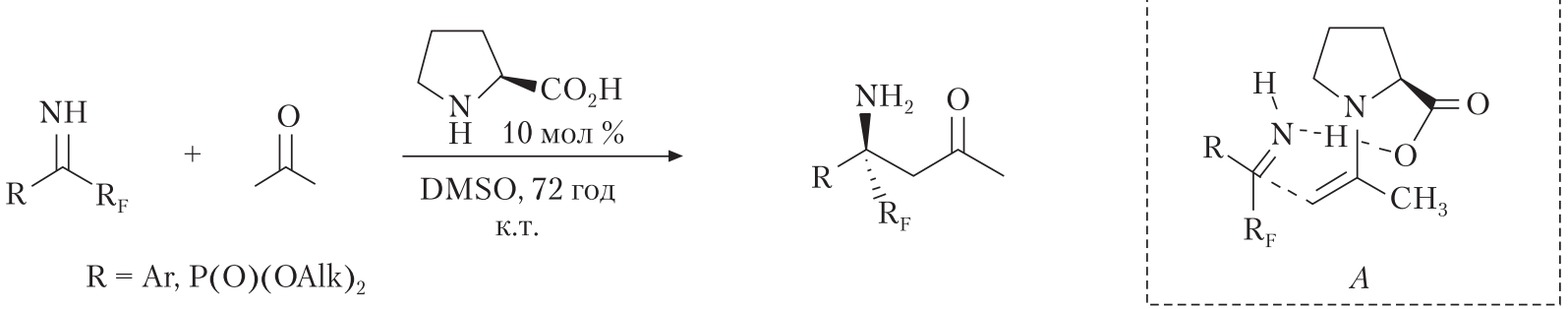

Puc. 1. Енантіоселективна органокаталітична реакція Манніха фтороалкілкетімінів

такі тіосечовинні каталізатори можна застосовувати для інших реакцій, і це стало початком загального використання енантіоселективного каталізу за допомогою утворення водневих зв’язків.

Загалом функціональна роль каталізатора полягає як в активації електрофільного або нуклеофільного субстрату, так і в утворенні асиметричного середовища, відповідального за надання хіральності цільовим продуктам. За характером взаємодії із субстратом органокаталізатори класифікують на ковалентні і нековалентні. У першому випадку має місце утворення ковалентного зв'язку між каталізатором та субстратом, а у другому - активація субстрату відбувається завдяки формуванню водневих або іонних зв'язків. Типовими представниками ковалентних органокаталізаторів є аміносполуки та карбени, а нековалентних тіосечовини, органофосфорні кислоти та цинхонові алкалоїди.

Нові напрями асиметричного органокаталізу. Останніми роками спостерігається тісне поєднання асиметричного органокаталізу 3 фотокаталізом. Незважаючи на потенційно екологічні властивості фотокаталізу, часто виникає проблема, пов'язана 3 досягненням повного стереохімічного контролю у фотохімічній реакції, яка зумовлена високою реакційною здатністю радикалів. Цю проблему було позитивно вирішено завдяки поєднанню Д. Макмілланом єнаміноопосередкованого ковалентного каталізу і фотоокиснювального каталізу [3]. У 2016 р. П. Мельхіорре застосував активацію імінію у фотокаталізі для отримання $\beta, \beta$-дизаміщених циклічних єнонів з високою енантіочистотою в асиметричній побудові четвертинних вуглецевих стереоцентрів [13]. Подвійну каталітичну систему з нековалентним органокаталізом вдалося успішно реалізувати групі Р. Ноулза [14], яка стала піонером у використанні хіральної похідної фосфорної кислоти в асиметричному фотокаталізі. Застосування цього каталітичного режиму дозволило здійснити міжмолекулярне декарбоксилювальне крос-сполучення $\mathrm{N}$-ацетил-Lфенілаланіну з 3- та 4-метилхіноліном.

Наукова група Б. Ліста [15] запропонувала органотекстильний каталіз, який грунтується на фотохімічному закріпленні органокаталізаторів на текстильному нейлоні через радикальний процес. Такі органокаталізатори продемонстрували прекрасну сумісність 3 поліамідним волокном, що дозволило отримати їх гетерогеннні представники, які містили основи Льюїса, кислоти Бренстеда та хіральні похідні цинхонового алкалоїда. Цей підхід дав змогу вирішити проблему рециклізації в класичному органокаталізі: майже ідеальна енантіоселективність зберігалася після 250 асиметричних каталітичних циклів. Така вражаюча стійкість каталізаторів на основі органотекстилю є вагомою підставою для їх успішного застосування у промисловому виробництві.

Асиметричне органокаталітичне нуклеофільне приєднання, як правило, здійснюється шляхом каталізу водневими зв'язками, однак через незначну кислотність таких хіральних донорів, як тіосечовини, сквараміди та іони гуанідинію, має місце несумісність деяких типів субстратів, що було виправлено введенням кислоти Льюїса як співкаталізатора. Так, Б. Ліст і співавтори розробили надзвичайно активний каталізатор на базі кислоти Льюїса,

ISSN 1027-3239. Visn. Nac. Acad. Nauk Ukr. 2021. (12) 
отриманий силілюванням in situ із хіральних C-Н-кислот, для ініціювання асиметричної реакції Дільса-Альдера [16].

Інтенсивні дослідження значно розширили межі органокаталізу для отримання атропоізомерів. Наукова група Б. Тана [17] досягла значних успіхів у побудові аксіально-хіральних структур, зокрема привілейованих NOBIN i BINAM, за допомогою органокаталізу, а С. Міллер зі співавторами [18] розробили короткі пептиди як прототипи біоміметичних каталізаторів, у тому числі й для каталізу за допомогою водневих зв'язків. Використання органокаталізаторів і лігандів з аксіально-хіральним елементом дозволило вирішити проблеми асиметричного синтезу багатокомпонентних реакцій Угі та Пассеріні, які відомі високою атомекономністю, що дуже важливо в орієнтованому на різноманіття синтезі складних молекул.

Досягнення українських вчених у галузі асиметричного органокаталізу. У розвиток асиметричного органокаталізу гідний внесок зробили і вітчизняні науковці. В Інституті органічної хімії НАН України д.х.н. В.А. Сукач і д.х.н. М.В. Вовк зі співробітниками на основі каталізованої L-проліном реакції Манніха арилтрифторометилкетімінів з ацетоном створили ефективний енантіоселективний метод синтезу нових хіральних реагентів - фторовмісних похідних $\beta$-амінокетонів [19]. Синтетичний потенціал асиметричної органокаталітичної реакції Манніха розкрили д.Х.н. Ю.В. Рассукана і д.х.н. П.П. Онисько зі співробітниками на прикладах похідних імінофосфонових кислот, що стало підгрунтям для побудови оптично активних $\alpha$-імінотрифтороетилфосфонатів [20, 21]. Такі процеси реалізуються з високою хемо- та енантіоселективністю і приводять до цільових продуктів з енантіомерною чистотою 78-92 \%. Стереохімічний результат реакції відповідає перехідному стану $A$ (рис. 1), сформованому з енергетично більш вигідної антиконфігурації проміжного єнаміну.

Не менш важливими видаються результати 3 каталізованої хіральними вторинними амінами рівноважної реакції 4-трифторометил-

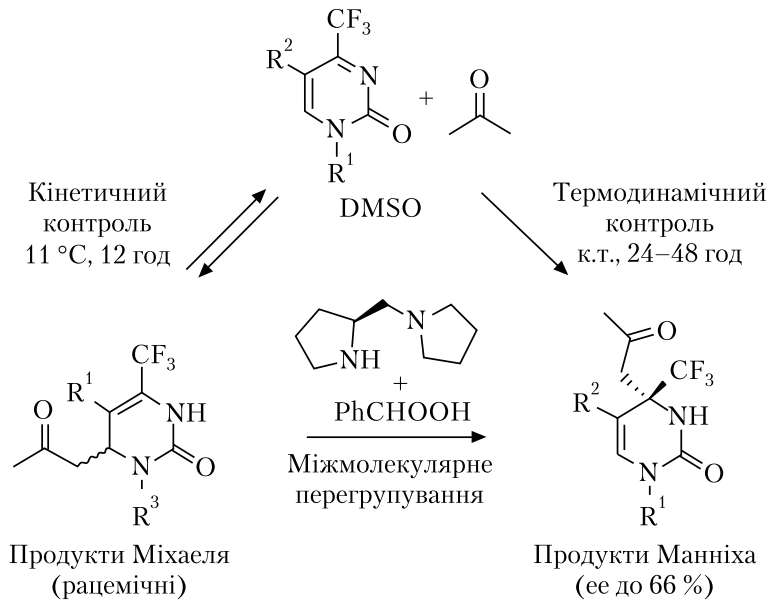

Puc. 2. Асиметрична органокаталітична реакція Манніха 4-трифторометилпіримідин-2(1Н)онів

піримідин-2-онів з ацетоном, у якій продукти Міхаеля утворюються в умовах кінетичного контролю і схильні до перегрупування за міжмолекулярним механізмом в ізомерні термодинамічно стабільні продукти Манніха (рис. 2). Останні було отримано в енантіозбагаченій формі при застосуванні хірального органокаталізатора (S)-(+)-1-(2-піролідинілметил)піролідину (ПМП) в присутності кислот Бренстеда [22].

Крім описаних у літературі органокаталізаторів для проведення нових асиметричних хімічних реакцій, в Інституті розробляють нові типи хіральних органокаталізаторів. Для їх дизайну академік НАН України В.I. Кальченко зі співробітниками застосували принципи і методи фосфорорганічної та супрамолекулярної хіміі, а в ролі молекулярних платформ використали легкодоступні макроциклічні сполуки - каліксарени. Завдяки своїй оригінальній чашоподібній архітектурі каліксарени можуть з високою селективністю, що наближається до селективності природних ензимів, розпізнавати і зв’язувати в супрамолекулярні комплекси органічні молекули різної природи. Каліксарени мають також практично необмежені можливості хімічної модифікації верхнього та нижнього вінця макроциклу різноманітними функціональними групами, в тому числі ка- 

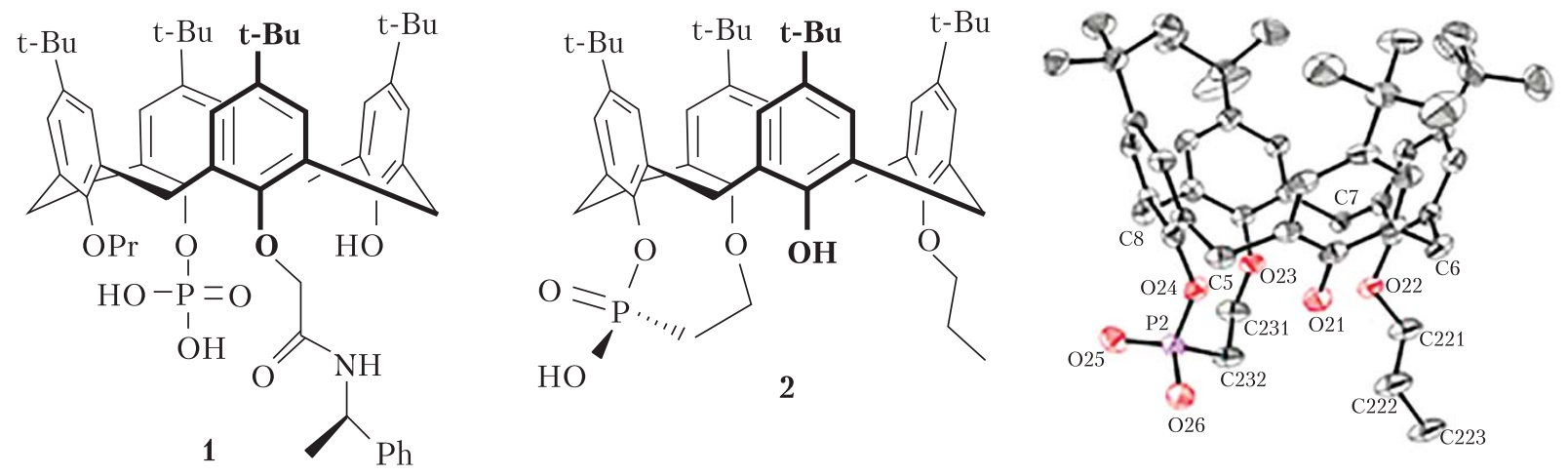

$\boldsymbol{P u c . 3 . ~ Е н а н т і о м е р н о ~ ч и с т і ~ в н у т р і ш н ь о х і р а л ь н а ~ к а л і к с а р е н ф о с ф о р н а ~ к и с л о т а ~} \mathbf{1}$ і каліксаренфосфонова кислота 2 , а також молекулярна структура кислоти 2<smiles>[R]c1ccc(/C=N/c2c([R])cccc2[R])c([R])c1</smiles>

Puc. 4. Органокаліз асиметричної реакції аза-Дільса-Альдера каліксаренами

Puc. 5. Асиметричне органокаталітичне $\alpha$-бензилювання альдегідів<smiles>CC(C=O)C([N-])[Al]</smiles>

$(\mathrm{RO})_{2} \mathrm{P}(\mathrm{O}) \mathrm{H}+\mathrm{ArCH}=\mathrm{O}$ 
талітично активними. При функціоналізації молекулярної платформи каталітично активними хіральними замісниками або при їі асиметричному заміщенні каталітично активними ахіральними замісниками каліксарени стають оптично активними і набувають здатності до супрамолекулярного асиметричного органокаталізу [23].

Використовуючи такі підходи, колектив науковців під керівництвом В.I. Кальченка у співпраці з кафедрою органічної хімії Київського національного університету імені Тараса Шевченка та лабораторією координаційних сполук Університету імені Поля Сабатьє міста Тулуза синтезували та дослідили енантіомерно чисті асиметрично заміщені (внутрішньохіральні) каліксарени 1, 2, модифіковані по нижньому вінцю макроциклу каталітично активними угрупованнями фосфорної та фосфонової кислоти (рис. 3) [24, 25].

Отримані внутрішньохіральні каліксаренфосфорна та каліксаренфосфонова кислоти 1, 2 каталізують асиметричні реакції аза-Дільса-Альдера та асиметричного розкриття нуклеофілами симетричних епоксидів, які ведуть до практично корисних хіральних сполук (рис. 4).

На особливу увагу заслуговує дослідження, виконане професором КНУ імені Тараса Шев- ченка I.В. Комаровим зі співробітниками у співпраці із цьогорічним нобелівським лауреатом Б. Лістом і присвячене органокаталітичному асиметричному $\alpha$-бензилюванню альдегідів бензилбромідами [26]. Авторам вдалося досягти найвищої ентіоселективності процесу при використанні як органокаталізаторів стерично утруднених каркасних аналогів проліну, отриманих науковою групою I.В. Комарова (рис. 5).

Значний внесок у створення хіральних фосфорорганічних реагентів та їх органокаталітичних перетворень зроблено в Інституті біоорганічної хімії та нафтохімії ім. В.П. Кухаря НАН України членом-кореспондентом НАН України О.І. Колодяжним [27]. В дослідженні гідрофосфонілювання альдегідів у присутності хініну як органокаталізатора було встановлено, що енантіоселективність таких реакцій суттєво підвищується при введенні в них хірального диментилфосфіту внаслідок подвійної асиметричної індукції (рис. 6) [28, 29].

Отже, отримані українськими науковцями результати в галузі асиметричного органокаталізу органічно вписуються в контекст світових досліджень і є надійним підгрунтям подальшого потужного розвитку цього важливого інструменту розв'язання актуальних проблем сучасного тонкого органічного синтезу, медичної та фармацевтичної хімії.

\section{REFERENCES}

\section{[СПИСОК ЛІТЕРАТУРИ]}

1. List B., Lerner R.A., Barbas C.F. III. Proline-catalyzed direct asymmetric aldol reactions. J. Amer. Chem. Soc. 2000. 122(10): 2395-2396. DOI: https://doi.org/10.1021/ja994280y

2. Ahrendt K.A., Borths C.J., MacMillan D.W.C. New strategies for organic catalysis: the first highly enantioselective organocatalytic Diels-Alder reaction.J. Amer. Chem. Soc. 2000. 122(17): 4243-4244. DOI: https://doi.org/10.1021/ ja000092s

3. Nicewicz D.A., MacMillan D.W.C. Merging photoredox catalysis with organocatalysis: the direct symmetric alkylation of aldehydes. Science. 2008. 322(5898): 77-80. DOI: https://doi.org/10.1126/science.1161976

4. Gomollón-Bel F. Ten chemical innovations that will change our world: IUPAC identifies emerging technologies in Chemistry with potential to make our planet more sustainable. Chem. Int. 2019. 41(2): 12-17. DOI: https://doi. org/10.1515/ci-2019-0203

5. MacMillan D.W.C. The advent and development of organocatalysis. Nature. 2008. 455: 304-308. DOI: https://doi. org/10.1038/nature07367

6. King H.D., Meng Z., Denhart D., Mattson R., Kimura R., Wu D., Gao Q., Macor J.E. Enantioselective synthesis of a highly potent selective serotonin reuptake inhibitor. An application of imidazolidinone catalysis to the alkylation of indoles with an $\alpha, \beta$-disubstituted $\alpha, \beta$-unsaturated aldehyde. Org. Lett. 2005. 7(16): 3437-3440. DOI: https://doi. org/10.1038/nature17438 
7. Hajos Z.G., Parrish D.R. Asymmetric synthesis of optically active polycyclic organic compounds. German patent DE 2102623 (1971).

8. Eder U., Sauer G.R., Wiechert R. Optically active 1,5-indanone and 1,6-naphthalenedione derivatives. German patent DE 2014757 (1971).

9. Lelais G., MacMillan D.W.C. Modern strategies in organic catalysis: the advent and development of iminium activation. Aldrichim. Acta. 2006. 39 (3): 79-87.

10. Oku J.I., Inoue S. Asymmetric cyanohydrin synthesis catalyzed by a synthetic cyclic dipeptide.J. Chem. Soc. Chem. Commun. 1981. (5): 229-230. DOI: https://doi.org/10.1039/C39810000229

11. Hiemstra H., Wynberg H. Addition of aromatic thiols to conjugated cycloalkenones, catalyzed by chrial $\beta$-hydroxy amines. A mechanistic study on homogeneous catalytic asymmetric synthesis. J. Amer. Chem. Soc. 1981. 103(2): 417430. DOI: https://doi.org/10.1021/ja00392a029

12. Sigman M., Jacobsen E.N. Schiff base catalysts for the asymmetric Strecker reaction identified and optimized from parallel synthetic libraries. J. Amer. Chem. Soc. 1988. 120(19): 4901.

13. Murphy J.J., Bastida D., Paria S., Fagnoni M., Melchiorre P. Asymmetric catalytic formation of quaternary carbons by iminium ion trapping of radicals. Nature. 2016. 532: 218-222. DOI: https://doi.org/10.1038/nature17438

14. Rono L.J., Yayla H.G., Wang D.Y., Armstrong M.F., Knowles R.R. Enantioselective photoredox catalysis enabled by proton-coupled electron transfer: development of an asymmetric aza-pinacol cyclization. J. Amer. Chem. Soc. 2013. 135(47): 17735-17738. DOI: https://doi.org/10.1021/ja4100595

15. Lee J.-W., Mayer-Gall T., Opwis K., Song C.E., Gutmann J.S., List B. Organotextile catalysis. Science. 2013. 341(6151): 1225-1229. DOI: https://doi.org/10.1126/science.1242196

16. Gatzenmeier T., Van Gemmeren M., Xie Y., Hofler D., Leutzsch M., List B. Asymmetric Lewis acid organocatalysis of the Diels-Alder reaction by a silylated C-H acid. Science. 2016. 351(6276): 949-952. DOI: https://doi.org/10.1126/ science.aae0010

17. Wang Y.-B., Tan B. Construction of axially chiral compounds via asymmetric organocatalysis. Acc. Chem. Res. 2018. 51(2): 534. DOI: https://doi.org/10.1021/acs.accounts.7b00602

18. Metrano A.J., Miller S.J. Peptide-based catalysts reach the outer sphere through remote desymmetrization and atroposelectivity. Acc. Chem. Res. 2019. 52(1): 199-215. DOI: https://doi.org/10.1021/acs.accounts.8b00473

19. Sukach V.A., Golovach N.M., Pirozhenko V.V., Rusanov E.B., Vovk M.V. Convenient enantioselective synthesis of $\beta$-trifluoromethyl- $\beta$-aminoketones by organocatalytic asymmetric Mannich reaction of aryl trifluoromethyl ketimines with acetone. Tetrahedron: Asymmetry. 2008. 19(6): 761-764. DOI: https://doi.org/10.1016/j.tetasy.2008.02.023

20. Rassukana Yu.V., Yelenich I.P., Vlasenko Yu.G.. Onys'ko P.P. Asymmetric synthesis of phosphonotrifluoroalanine derivatives via proline-catalyzed direct enantioselective $\mathrm{C}-\mathrm{C}$ bond formation reactions of $\mathrm{N}-\mathrm{H}$ trifluoroacetimidoyl phosphonate. Tetrahedron: Asymmetry. 2014. 25(16-17): 1234-1238. DOI: https://doi.org/10.1016/j.tetasy.2014.07.007

21. Rassukana Yu.V., Stanko O.V., Onys'ko P.P. Enantiomeric O,O-dimenthyl $\alpha$-iminotrifluoroethylphosphonates: novel chiral building blocks in asymmetric of $\alpha$-trifluoromethylated $\alpha$-aminophosphonic acid derivatives. J. Fluor. Chem. 2019. 219: 123-128. DOI: https://doi.org/10.1016/j.jfluchem.2019.01.007

22. Sukach V.A., Tkachuk V.M., Shoba V.M., Pirozhenko V.V., Rusanov E.B., Chekotilo A.A., Roschenthaler G.-V., Vovk M.V. Control regio- and enantioselectivity in the asymmetric organocatalitic addition of acetone to 4-(trifluoromethyl)pyrimidin-2-(1H)-ones. Eur. J. Org. Chem. 2014. (7): 1452-1460. DOI: https://doi.org/10.1002/ ejoc. 201301542

23. Boiko V.I., Kalchenko V.I., Esipenko A.A. Chiral calixarenes. Saarbrücken: Lap Lambert Academic Publishing, 2014. [Бойко В.И., Кальченко В.И., Есипенко А.А. Хиральные каликсарены. Saarbrücken: Lap Lambert Acad. Publ., 2014].

24. Karpus A., Yesypenko O., Boiko V., Daran J.-C., Voitenko Z., Kalchenko V., Manoury E. Synthesis of a new enantiomerically pure inherently chiral calix[4]arene phosphonic acid and its first evalution as organocatalyst.J. Org. Chem. 2018. 83(3): 1146-1153. DOI: https://doi.org/10.1021/acs.joc.7b02312

25. Karpus A., Yesypenko O., Cherenok S., Boiko V., Kalchenko O., Voitenko Z., Tribrat O., Poli R., Daran J.-C., Manoury E., Kalchenko V. Chiral phosphorus-containing calixarenes. Phosphorus, Sulfur, Silicon and the related Elements. 2019. 194(4-6): 471-475. DOI: https://doi.org/10.1080/10426507.2018.1539994

26. List B., Čorić I., Grygorenk O.O., Kaib P.S., Komarov I., Lee A., Leutzsch M., Pan S.C., Tymtsunik A.V., van Gemmeren M. The Catalytic Asymmetric $\alpha$-Benzylation of Aldehydes. Angew. Chem. Int. Ed. 2014. 53(1): 282-285. DOI: https://doi.org/10.1002/anie.201306037

27. Kolodiazhnyi O.I., Kolodiazhna A.O. Asymmetric synthesis of organophosphorus compounds. Kyiv: Naukova dumka, 2017. 
[Колодяжный О.И., Колодяжная А.О. Стереоселективный синтез фосфорорганических соединений. Киев: Наукова думка, 2017.]

28. Kolodyazhnaya A.O., Kukhar V.P., Kolodyazhnyi O.I. Organic catalysis of phospha-aldol condensation. Russ.J. Gen. Chem. 2008. 78(11): 2043-2051. DOI: https://doi.org/10.1134/S1070363208110091

29. Kolodyazhnaya A.O., Kukhar V.P., Kolodyazhnyi O.I. Modified alkaloid as organocatalysts for the asymmetric synthesis of organophosphorus compounds. Phosphorus, Sulfur and Silicon. 2008. 183(1-2): 728-729. DOI: https://doi. org/10.1080/10426500701807673

\section{Mykhailo V. Vovk}

Institute of Organic Chemistry of the National Academy of Sciences of Ukraine ORCID: https://orcid.org./0000-0003-1753-3535

\section{ASYMMETRIC ORGANOCATALYSIS - A NEW STRATEGY FOR THE CONSTRUCTION OF CHIRAL MOLECULES FOR MODERN ENGINEERING, TECHNOLOGY, AND MEDICINE}

A brief review article shows key aspects of the formation and development of asymmetric organocatalysis over the past two decades as a powerful new tool for the design of chiral organic molecules. The role of the creators of asymmetric organocatalysis strategy Benjamin List and David MacMillan, who were awarded the Nobel Prize in Chemistry in 2021, is emphasized. The fundamental advantages of the organocatalytic methodology in comparison with other methods of asymmetric synthesis have been revealed. The most typical methods of asymmetric organocatalysts activation have been analyzed and examples of new directions of their use have been given. Special attention is paid to the results of the Ukrainian scientists' research in the field of organic organocatalysis.

Keyzords: asymmetric organocatalysis, chiral molecules, methods of activation of organocatalysts, achievements of Ukrainian researchers. 